\title{
Daniel Setcki
}

Uniwersytet Mikołaja Kopernika, Toruń

daniel.setcki@gmail.com

ORCID: https://orcid.org/0000-0002-1491-5557

\section{Glosa do wyroku Sądu Najwyższego z dnia 23 lutego 2017 r., I CSK 232/16}

http://dx.doi.org/10.12775/SIT.2018.044

Teza wyroku:

Uchwałą zgromadzenia wspólników spółki z ograniczoną odpowiedzialnością nie można skutecznie obciążyć wspólników opłatami związanymi z ochroną wspólnego znaku towarowego (art. 136 Ustawy z dnia 30 czerwca 2000 r. - Prawo własności przemysłowej, t.j. Dz.U. z 2017 r. poz. 776), jeżeli taki obowiązek nie wynika z umowy spółki (art. 159 k.s.h.).

W komentowanym orzeczeniu przedmiotem rozważań Sądu Najwyższego był problem skutecznego sposobu nakładania na wspólników spółek z ograniczoną odpowiedzialnością innych obowiązków aniżeli określony w art. 151 k.s.h. obowiązek pokrycia obejmowanych udziałów. Kwestia ta może mieć istotne znaczenie dla stosunków wewnętrznych panujących w spółkach i dla obrotu gospodarczego w związku ze zbywaniem i nabywaniem udziałów. Należy bowiem mieć na uwadze fakt, że strony w szerokim zakresie mogą swobodnie kształtować treść umowy spółki. Może się zatem zdarzyć, że jej postanowienia okażą się niejasne, sprzeczne ze sobą, a w kontekście nakładania dodatkowych obowiązków strony umowy mogą także całkowicie pominąć ich uregulowanie, starając się je następnie nakładać m.in. w drodze uchwał zgromadzenia wspólników. 
Problem skutecznego nakładania dodatkowych obowiązków na wspólników jest przedmiotem rozważań doktrynalnych, natomiast dotychczas brak było orzeczenia Sądu Najwyższego poruszającego tę problematykę. Co prawda, w komentowanym orzeczeniu sąd ten, ze względu na niedostateczne ustalenia sądów meriti w zakresie wykładni postanowień umowy spółki, skierował sprawę do ponownego rozpoznania, jednakże w treści uzasadnienia szeroko odniósł się do powyższego problemu i trafnie opowiedział się za ścisłą wykładnią treści art. 159 k.s.h. w relacji do art. 151 k.s.h.

Orzeczenie zapadło w następującym stanie faktycznym. Otóż na wspólników spółki nałożony został dodatkowy obowiązek, polegający na regularnym uiszczaniu opłat związanych $z$ ochroną wspólnego znaku towarowego, o którym mowa w art. 136 Ustawy z dnia 30 czerwca 2000 r. Prawo własności przemysłowej (tj.: Dz.U. z 2017 r., poz. 776 ze zm.), reprezentowaniem wspólników w instytucjach centralnych, organizowaniem spotkań wspólników z kontrahentami i spotkań tematycznych. Podstawa tego obowiązku została określona w uchwale zgromadzenia wspólników podjętej jednogłośnie w 2008 r. Przez następne parę lat zgodnej współpracy wspólników corocznie były podejmowane przez zgromadzenia wspólników tzw. uchwały wykonawcze, które określały szczegółowe kwoty pieniężne, jakie każdy ze wspólników miał uiścić w danym roku kalendarzowym w związku $z$ dodatkowym obowiązkiem określonym w uchwale podjętej w 2008 r. Na zgromadzeniu wspólników w dniu 15 grudnia 2011 r., na którym głosowana była kolejna tzw. uchwała wykonawcza, jeden ze wspólników zagłosował przeciw, a następnie wytoczył powództwo o stwierdzenie jej nieważności lub o jej uchylenie. Sądy meriti oddaliły powództwo, stwierdzając, że nie było podstaw do jego uwzględnienia.

Istota powstałego sporu sprowadzała się do tego, czy dodatkowe obowiązki nakładane na wspólników w ramach stosunku korporacyjnego mogą zostać skutecznie nałożone w uchwale podjętej przez zgromadzenie wspólników.

Zgodnie $z$ brzmieniem art. 159 k.s.h., jeżeli wspólnikowi mają być przyznane szczególne korzyści lub jeżeli na wspólników mają być nałożone, oprócz wniesienia wkładów na pokrycie udziałów, inne obowiązki wobec spółki, należy to pod rygorem bezskuteczności 
wobec spółki dokładnie określić w umowie spółki. Sąd Najwyższy, dokonując odpowiedniej wykładni tego przepisu w komentowanym orzeczeniu, doszedł do wniosku, że umowa spółki powinna, co najmniej w sposób pośredni, tj. w drodze odpowiedniej wykładni oświadczeń woli (art. 65 k.c.), umożliwić ustalenie treści dodatkowych obowiązków nakładanych na wspólników.

Jeżeli zatem postanowienia umowy spółki w ogóle nie regulują kwestii dodatkowych obowiązków lub ograniczają się do zbyt ogólnych stwierdzeń, które nie pozwalają skonkretyzować ich treści, to w takiej sytuacji nie jest możliwe skuteczne powstanie dodatkowych obowiązków nakładanych na wspólników w ramach stosunku korporacyjnego.

W oparciu zatem o rozumowanie a fortiori Sąd Najwyższy podkreślił, że skoro niewłaściwe ujęcie odpowiednich postanowień umowy spółki nie jest wystarczające do skutecznego powstania dodatkowych obowiązków, to tym bardziej ich źródłem nie mogą być korporacyjne mechanizmy podejmowania decyzji, jakimi w spółce z ograniczoną odpowiedzialnością są uchwały zgromadzenia wspólników. Brak jest ku temu podstawy prawnej.

Przedstawione w komentowanym orzeczeniu stanowisko Sądu Najwyższego należy w pełni podzielić. Można je jednak jeszcze dodatkowo poprzeć kilkoma argumentami, które prezentowane są w doktrynie prawa handlowego. Wymaga podkreślenia, że prezentowana przez Sąd Najwyższy wykładnia treści art. 159 k.s.h. jest zgodna z powszechnie aprobowanym w doktrynie poglądem, iż dodatkowe obowiązki nakładane na wspólników w ramach stosunku korporacyjnego powinny w sposób wyraźny wynikać $\mathrm{z}$ umowy spółki. Za takim rozwiązaniem przemawia przede wszystkim wykładnia literalna art. 159 k.s.h. W literaturze wskazuje się, że opis dodatkowych obowiązków nie powinien budzić wątpliwości odnośnie do istotnej treści sposobu wykonania obowiązków, ich zakresu i rodzaju, terminu wykonania oraz wysokości zobowiązania ${ }^{1}$.

${ }^{1}$ A. Szajkowski, M. Tarska, w: Kodeks spótek handlowych. Komentarz do art. 151-300 k.s.h., t. II, red. A. Szajkowski, M. Tarska, Warszawa 2005, s. 114; A. Kidyba, Kodeks spółek handlowych. Komentarz do art. 1-300 k.s.h., t. I, 
Na uwagę zasługuje również argument natury historycznoprawnej, oparty na analizie przepisów Kodeksu handlowego ${ }^{2}$, a konkretnie treści art. 164 k.h., który był odpowiednikiem obecnie obowiązującego art. 159 k.s.h. Przepis ten regulował kwestię dodatkowych obowiązków wspólników i stanowił, że: „Jeżeli spólnikowi mają być przyznane szczególne korzyści lub jeżeli na spólników mają być nałożone oprócz pokrycia udziałów inne obowiązki wobec spółki, należy to zastrzec w umowie spółki”. Skoro zatem ustawodawca, tworząc nowy Kodeks spółek handlowych, nie tylko zachował wymóg ujęcia dodatkowych obowiązków w treści umowy spółki, lecz ponadto dodał przymiotnik „dokładnie”, to znaczy, że jego intencją było nie tylko zobowiązanie wspólników do ujęcia stosownych dodatkowych obowiązków w treści umowy spółki, ale także podkreślenie doniosłości jak najpełniejszego ich opisania.

W doktrynie przeważa pogląd, że art. 159 k.s.h. dotyczy zarówno obowiązków o charakterze podmiotowym (osobistym), czyli związanych z osobą wspólnika, jak i obowiązków o charakterze przedmiotowym (związanych $z$ udziałem) ${ }^{3}$. Generalnie należy zatem stwierdzić, że dodatkowe obowiązki mogą wynikać $z$ ujęcia w umowie spółki odpowiednich dyspozytywnych w tym zakresie przepisów Kodeksu spółek handlowych lub zostać stworzone przez same strony umowy spółki, zgodnie $z$ obowiązującą zasadą swobody umów (art. $353^{1}$ k.c. w zw. $z$ art. 2 k.s.h.).

Warszawa 2011, s. 656; R. Kowalkowski, w: Kodeks spótek handlowych. Komentarz, red. Z. Koźmy, M. Ożóg, Gdańsk 2012, s. 264.

${ }^{2}$ Rozporządzenie Prezydenta Rzeczypospolitej z dnia 27 czerwca $1934 \mathrm{r}$. Kodeks handlowy, Dz.U. z 1934 r. Nr 57, poz. 502 ze zm.

${ }^{3}$ R. Potrzeszcz, w: Kodeks spótek handlowych. Komentarz, t. 2, red. T. Siemiątkowski, R. Potrzeszcz, Warszawa 2011, s. 53-55; A. Kidyba, Kodeks spółek handlowych, s. 654-655; R. Kowalkowski, w: Kodeks spółek handlowych, s. 263-264. Odmiennie M. Rodzynkiewicz, Kodeks spótek handlowych. Komentarz, Warszawa 2014, s. 264. Autor twierdzi, że art. 159 k.s.h. dotyczy wyłącznie obowiązków związanych z osobą wspólnika (osobistych). Nieczytelne wydaje się stanowisko R. Pabisa, który w zakresie dodatkowych przywilejów wskazuje, że art. 159 k.s.h. ma zastosowanie wyłącznie do uprawnień o charakterze osobistym, a w zakresie dodatkowych obowiązków takiego rozróżnienia nie wskazuje, zob.: R. Pabis, w: Kodeks spółek handlowych. Komentarz, red. 
Do tej pierwszej grupy należą obowiązek powtarzających się świadczeń niepieniężnych (art. 176 k.s.h.) oraz obowiązek dopłat (art. 177-179 k.s.h.). Redakcja obu przepisów jednoznacznie wskazuje, że obowiązki te, by były skuteczne, muszą zostać określone w umowie spółki i podlegają uszczegółowieniu. W przypadku powtarzających się świadczeń niepieniężnych w umowie spółki należy oznaczyć rodzaj (przedmiot świadczenia) i ich zakres ${ }^{4}$. W razie natomiast obowiązku dopłat nie jest wystarczające wspomnienie o nich w umowie spółki, lecz ponadto wymagane jest wskazanie liczbowo oznaczonej granicy wysokości dopłat w stosunku do udziału. Na uwagę zasługuje jednak fakt, że oznaczenie tej ogólnej granicy jest wyłącznie swoistym sposobem limitacji przewidzianego obowiązku, gdyż szczegółowa treść każdej konkretnej dopłaty, taka jak wysokość i termin, jest ostatecznie precyzowana w podejmowanych uchwałach przez zgromadzenie wspólników ${ }^{5}$. W konsekwencji należy stwierdzić, że skoro ustawodawca uzależnia skuteczność nałożenia dodatkowych obowiązków, rodzajowo przewidzianych jednak w dyspozytywnych przepisach Kodeksu spółek handlowych, nie tylko od ich lakonicznego ujęcia w umowie spółki, ale także od ich odpowiedniego opisania, to rozumując a fortiori, należy stwierdzić, że tym większej precyzji wymagać się powinno względem skutecznego nałożenia na wspólników dodatkowych obowiązków opartych wyłącznie na podstawie zasady swobody umów.

Nie tylko wykładnia literalna i systemowa przemawiają za stanowiskiem, że nie można w drodze uchwały zgromadzenia wspólników skutecznie nakładać dodatkowych obowiązków, lecz również wykładnia celowościowa art. 159 k.s.h. Należy bowiem przyjąć za trafny wyrażany w doktrynie pogląd, że głównym celem uzależnienia skuteczności nakładania dodatkowych obowiązków na wspólników wobec spółki od jego dokładnego określenia w umowie spółki jest przede wszystkim ochrona interesów samych wspólników, a szerzej

J. Bieniak, M. Bieniak, G. Nita-Jagielski, K. Oplustil, R. Pabis, A. Rachwał, M. Spyra, G. Suliński, M. Tofel, R. Zawłocki, Warszawa 2015, s. 530-532.

4 A. Rachwał, w: System prawa handlowego. Prawo spółek handlowych, t. 2, red. S. Włodyka, Warszawa 2012, s. 745 .

${ }^{5}$ Zob. szerzej: ibidem, s. 746-747. 
ujmując: względy bezpieczeństwa obrotu ${ }^{6}$. O ile bowiem dodatkowe obowiązki nakładane na wspólników o charakterze osobistym wygasają $\mathrm{z}$ chwilą ustania członkostwa danego wspólnika w spółce, o tyle obowiązki takie trwają nadal, jeżeli są związane z posiadanym udziałem. Przyjęcie zatem odmiennego poglądu aniżeli prezentuje Sąd Najwyższy prowadziłoby w konsekwencji do tego, że potencjalny nabywca udziału miałby obowiązek nie tylko zapoznać się z treścią umowy spółki, co może obecnie uczynić chociażby we właściwym sądzie rejestrowym, ale musiałby ponadto zapoznać się ze wszystkimi uchwałami, jakie dotychczas zostały podjęte przez organy spółki, w tym przez zgromadzenie wspólników. Stawianie takich wymogów nie tylko skomplikowałoby i utrudniło obrót udziałami, ale znacznie zwiększyłoby ryzyko wystąpienia nadużyć ze strony nierzetelnych zbywców.

Abstrahując od stanu faktycznego sprawy, która była podstawą do wydania komentowanego orzeczenia, zwrócić należy uwagę, że Sąd Najwyższy trafnie zauważył, iż nawet jeżeli w konkretnym stanie faktycznym nie zostanie w umowie spółki skutecznie nałożony dodatkowy obowiązek na wspólników w ramach stosunku korporacyjnego, to nie wyklucza to prowadzenia dalszych zabiegów interpretacyjnych. Może się bowiem okazać, że w danym stanie faktycznym doszło do powstania stosunku zobowiązaniowego pomiędzy wspólnikami albo pomiędzy wspólnikami a spółką, odrębnego od łączącego ich stosunku korporacyjnego.

Pogląd ten należy w pełni zaaprobować, gdyż w związku z nowelizacją treści art. 159 k.s.h., dokonaną w 2004 r., sankcją za nienależyte uregulowanie dodatkowych obowiązków korporacyjnych nie jest ich nieważność, lecz wyłącznie ich bezskuteczność wobec spółki. To prowadzi do wniosku, że w przypadku niewłaściwego ujęcia danego dodatkowego obowiązku w treści umowy spółka nie może skutecznie dochodzić od wspólnika wykonania takiego obowiązku korporacyjnego. Nie przekreśla to jednak odpowiedniej wykładni postanowień umowy spółki w oparciu o art. 65 k.c., zmierzającej do ustalenia, że mogło dojść do ukształtowania, skutecznego inter

${ }^{6}$ A. Nowacki, Spółka z ograniczona odpowiedzialnością. Komentarz do art. 151-226 KSH, t. I, Nb 3, Legalis 2018. 
partes, innego stosunku zobowiązaniowego. Nie ma bowiem formalnych przeciwskazań, aby treść takiego odrębnego stosunku została ujęta, od strony technicznej, w treści samej umowy spółki, uchwałach zgromadzenia wspólników czy nawet w formie dorozumianej. Nie jest to oczywiście praktyka zalecana, jednak jest ona dozwolona. Także w literaturze wskazuje się, że w przypadku braku skutecznego nałożenia dodatkowych obowiązków na wspólników w ramach stosunku korporacyjnego może dojść do zawarcia tzw. umowy wspólników, która określa dodatkowe zobowiązania wszystkich lub niektórych wspólników na rzecz spółki, poza stosunkiem korporacyjnym ${ }^{7}$.

Sąd Najwyższy w uzasadnieniu komentowanego orzeczenia poszedł o krok dalej i dopuścił nawet zawarcie dorozumianej umowy pomiędzy wspólnikami a spółką. Pogląd ten również należy uznać za trafny, gdyż nawet w sytuacji, w której nie dochodzi do powstania dodatkowego obowiązku w ramach stosunku korporacyjnego lub do ukształtowania wyraźnego stosunku zobowiązaniowego pomiędzy wspólnikami, należy dążyć do prawidłowego ustalenia rzeczywistego stanu prawnego i ustalenia istniejących stosunków prawnych. Inną sprawą jest trudność w ustaleniu treści takiego konkretnego stosunku prawnego, jednak to leży już w zakresie obowiązków sądu, rozpatrującego konkretny stan faktyczny sprawy z uwzględnieniem całego materiału dowodowego oraz reguł wykładni przewidzianych w art. 65 k.c. ${ }^{8}$

Biorąc pod uwagę treść przepisów Kodeksu spółek handlowych oraz tezę orzeczenia Sądu Najwyższego, trudno wskazać jeden optymalny sposób ujmowania dodatkowych obowiązków nakładanych na wspólników w treści umowy spółki. Jest to trudniejsze w przypadku dodatkowych obowiązków nieprzewidzianych w dyspozytywnych przepisach tego kodeksu, gdyż ich treść determinowana będzie odmiennością każdego konkretnego stanu faktycznego. Zgodzić się jednak należy z przedstawionym stanowiskiem Sądu Najwyższego, że obowiązki takie nie mogą samoistnie wynikać $z$ uchwały zgro-

7 Z. Jara, w: Kodeks spótek handlowych. Komentarz, komentarz do art. 159, red. Z. Jara, Legalis 2017; R. Pabis, w: Kodeks spółek handlowych, s. 532.

${ }^{8}$ Wyrok SN z dnia 20 kwietnia 2011 r., I CSK 391/10, Legalis nr 385424. 
madzenia wspólników lub innego organu spółki. Co najwyżej taka uchwała może precyzować wyłącznie szczegółowy zakres danego obowiązku na podstawie jasnych kryteriów określonych uprzednio w treści umowy spółki. Kryteria takie mogą być oczywiście przedmiotem odpowiedniego sporu sądowego.

\title{
STRESZCZENIE
}

\author{
Glosa do Wyroku Sądu Najwyższego \\ z dnia 23 lutego 2017 r., I CSK 232/16
}

Sąd Najwyższy w wydanym wyroku rozważał kwestię skutecznego sposobu nałożenia dodatkowego obowiązku na wspólników spółki z ograniczoną odpowiedzialnością. Nie budziło wątpliwości, że jest to możliwe wówczas, gdy stanowi o tym wyraźnie umowa spółki, ale pytanie dotyczyło tego, czy możliwe jest nałożenie takiego obowiązku poprzez wydanie uchwały przez zgromadzenie wspólników. Sąd Najwyższy trafnie opowiedział się za ścisłą wykładnią art. 159 k.s.h. i w konsekwencji stwierdził, że tylko umowa spółki może skutecznie nałożyć dodatkowy obowiązek na wspólników. Glosa ma charakter aprobujący, ponadto są w niej zawarte dodatkowe argumenty prawne przemawiające za tezą orzeczenia wydanego przez Sąd Najwyższy.

Słowa kluczowe: umowa spółki; uchwała zgromadzenia wspólników spółki z o.o.; prawa i obowiązki

\section{SUMMARY}

\section{Gloss to the Supreme Court Judgment of 23 February 2017, I CSK 232/16}

The Supreme Court in its judgment, considered the issue how to effectively impose an additional obligation on the shareholders of a limited liability company (LLC). There was no doubt that this is possible when it is expressly stated in the articles of association, but the question was if it is possible to impose such an obligation by issuing a resolution by the shareholders' meeting? The Supreme Court was rightly in a favor of a strict interpretation of article 159 Code of commercial companies and consequently stated that only the articles of association can effectively impose an additional obligation on shareholders. Gloss has a supporting 
character, in which there are additional legal arguments in favor of the thesis issued by the Supreme Court.

Keywords: articles of association; resolution of the shareholder's meeting of LLC; rights and obligations

\section{BIBLIOGRAFIA}

Bieniak J., Bieniak M., Nita-Jagielski G., Oplustil K., Pabis R., Rachwał A., Spyra M., Suliński G., Tofel M., Zawłocki R. (red.), Kodeks spółek handlowych. Komentarz, Warszawa 2015.

Kidyba A., Kodeks spółek handlowych. Komentarz do art. 1-300 k.s.h., t. I, Warszawa 2011.

Koźmy Z., Ożóg M. (red.), Kodeks spótek handlowych. Komentarz, Gdańsk 2012.

Nowacki A., Spótka z ograniczoną odpowiedzialnością. Komentarz do art. 151-226 k.s.h., t. I, Warszawa 2018.

Rodzynkiewicz M., Kodeks spótek handlowych. Komentarz, Warszawa 2014.

Siemiątkowski T., Potrzeszcz R., Kodeks spółek handlowych. Komentarz, t. 2, Warszawa 2011.

Szajkowski A., Tarska M., Kodeks spótek handlowych. Komentarz do art. 151-300 k.s.h., t. II, Warszawa 2005.

Włodyka S., System prawa handlowego. Prawo spótek handlowych, t. 2, Warszawa 2012. 
